\title{
SIFAT ORGANOLEPTIK, KADAR KALSIUM, KADAR PROTEIN, DAN SIFAT FISIK MP-ASI BUBUR INSTAN BAYI SUBSTITUSI TEPUNG IKAN PEPETEK
}

\author{
${ }^{1}$ Ayu Amalia Tresna Dewi, ${ }^{2}$ Sumarto, ${ }^{3}$ Uun Kunaepah \\ ${ }^{1}$ Alumni Poltekkes Kemenkes Tasikmalaya \\ ${ }^{2,3}$ Dosen Poltekkes Kemenkes Tasikmalaya
}

\begin{abstract}
Abstrak
Tujuan penelitian ini adalah mendapatkan produk bubur instan yang dapat memenuhi kebutuhan gizi bayi usia 6-24 bulan dan secara organoleptik dapat disukai, serta dapat dijadikan alternatif pilihan MP-ASI. Jenis penelitian ini adalah eksperimental dengan desain penelitian rancangan acak kelompok (RAK). Panelis dalam penelitian ini merupakan panelis agak terlatih berjumlah 30 orang. Data dikumpulkan menggunakan formulir uji hedonik yang kemudian diolah menggunakan uji Anova, dan dilakukan uji lanjut dengan Duncan. Kadar protein dan kalsium produk bubur instan terbaik diperoleh melalui uji laboratorium dan diolah menggunakan metode deskriptif. Hasil uji statistik Anova menunjukkan produk bubur instan bayi dengan substitusi tepung ikan pepetek $50 \%$ merupakan produk terbaik terhadap parameter warna, aroma, tekstur, dan rasa dengan masing-masing nilai $p=0,000(p<0,05)$. Kadar protein pada produk bubur instan bayi dengan substitusi tepung ikan pepetek terbaik adalah $21,89 \%$ dan kadar kalsium 185,19 mg/100g.
\end{abstract}

Kata kunci : Bubur Instan Bayi, Tepung Ikan Pepetek, Organoleptik, Analisis Kalsium dan Protein

\begin{abstract}
The objective are get instant porridge products that can fulfil the nutritional needs of infants aged 6-24 months and organoleptic preferred, and can be used as an alternative option complementary feeding (MP-ASI). ANOVA ponyfish flour test results show instant baby porridge products with the substitution of $50 \%$ is the best product on the parameters color, aroma, texture, and flavor. With the results of each value of $p=0.000(p<0.05)$. Protein level in instant baby porridge products with the best common ponyfish flour substitution is $21.89 \%$ and 185.19 $\mathrm{mg}$ calcium levels/100g. This study shows that there are differences in color, aroma, texture, and flavor of the organoleptic properties of instant baby porridge with substitution of common ponyfish flour (Leiognathus sp.). Instant baby porridge best formula contained in the substitution of $50 \%$.
\end{abstract}

Keywords : Instant Baby Porridge, Common ponyfish flour, Organoleptic, Protein dan Calcium's Analysis

\section{PENDAHULUAN}

Masa bayi dan anak-anak merupakan masa yang paling penting dalam perkembangan manusia, karena pada masa ini terjadi pertumbuhan dan perkembangan yang akan menentukan kualitas sumberdaya manusia di masa yang akan datang. Masa ini juga merupakan masa yang rawan terhadap kekurangan zat gizi dan terserang penyakit. Kejadian kekurangan gizi pada bayi dan anak-anak dapat menyebabkan terjadinya gagal tumbuh (grouth faultering), yang akan mempengaruhi tumbuh kembang pada fasefase berikutnya (Fernando, 2008). Di dalam 
Global Strategy for Infant and Young Child Feeding, WHO/UNICEF merekomendasikan salah saatunya yang harus dilakukan untuk mencapai tumbuh kembang optimal adalah dengan memberikan makanan pendamping ASI (MP-ASI) sejak bayi berusia 6 bulan sampai 24 bulan (WHO, 2003).

Menurut data Susenas (2006) pada tahun 1989 prevalensi gizi kurang pada balita adalah $37,5 \%$, sedangkan pada tahun 2005 terjadi penurunan menjadi 28\%. Data ini menunjukkan masih tingginya prevalensi gizi kurang di Indonesia. Pemberian makanan tambahan (PMT) diharapkan mempunyai peranan penting dalam menanggulangi masalah kekurangan gizi pada bayi dan anak-anak.

Beberapa penelitian menunjukkan bahwa anak-anak Indonesia yang lahir dengan keadaan gizi baik akan bertahan hingga usia 6 bulan, setelah usia 6 bulan, keadaan gizi mulai menurun. Hal ini terjadi karena semakin meningkatnya kebutuhan gizi bayi, sementara produksi ASI semakin menurun dan pemberian makanan pendamping ASI (MP-ASI) belum sesuai dengan kecukupan gizi bayi. Kondisi tersebut di atas dapat menimbulkan kekurangan energi protein (KEP) pada bayi atau anak (Anonim, 2015)

Departemen Kesehatan RI menetapkan persyaratan kandungan gizi yang harus dipenuhi dalam $100 \mathrm{~g}$ bubur instan bayi antara lain kandungan energi minimal $400 \mathrm{Kkal}$, kandungan protein sebesar 15-22 g, dan kandungan kalsium 200-400 mg. Pemilihan bahan MP-ASI penting untuk memenuhi persyaratan tersebut. Dewasa ini telah banyak berkembang MP-ASI komersial yang tersedia dalam bentuk biskuit ataupun dalam bentuk tepung campuran instan yang dibuat dari campuran berbagai bahan pangan. Salah satu bentuk tepung campuran instant adalah bubur susu dengan bahan lain dari serealia, seperti beras dan susu serta ditambah gula (Apriadji \& Ariani 1989).

Salah satu bahan pangan lokal sumber protein yang dapat dimanfaatkan sebagai bahan MP-ASI adalah ikan. Produksi perikanan tangkap dari penangkapan ikan di laut dan di perairan umum pada tahun 2006 masing-masing sekitar 4.468.010 ton dan 301.501 ton (Ditjen Perikanan Tangkap, 2007). Indonesia memiliki potensi sumberdaya ikan diperkirakan sebanyak 6,26 juta ton pertahun. Sampai tahun 1999, potensi pemanfaatan sumberdaya ikan tersebut baru dimanfaatkan sebesar $76 \%$ dengan tingkat produksi sebesar 3,82 juta ton (Dahuri et al., 2001)

Indonesia memiliki potensi sumber daya perikanan yang sangat besar, tetapi belum dimanfaatkan secara optimal. Potensi tersebut salah satunya adalah ikan hasil tangkapan samping (HTS) atau by catch. Ikan HTS adalah ikan yang ikut tertangkap dalam suatu operasi penangkapan ikan tertentu yang sebenarnya tidak ditujukan untuk menangkap ikan tersebut. Salah satu ikan HTS yang belum dimanfaatkan secara optimal adalah ikan pepetek (Leiognathus $s p$.$) . Ikan pepetek memiliki ukuran yang$ kecil dan memiliki banyak duri sehingga di beberapa negara Asia Tenggara ikan ini lebih banyak digunakan untuk tepung ikan, pupuk, ikan asin dan pakan ternak. Di Indonesia, ikan pepetek lebih banyak dimanfaatkan sebagai pakan ternak dan ikan asin, oleh karena itu ikan pepetek merupakan ikan yang nilai ekonomisnya masih rendah (Putro et al., 2012).

Menurut Departemen Kelautan dan Perikanan (1997) kandungan gizi ikan pepetek dalam 100 gram berat dapat dimakan mengandung energi sebesar 176 kkal, protein sebesar $32 \mathrm{~g}$, lemak 4,4 g, dan karbohidrat $0,0 \mathrm{~g}$. Untuk mengoptimalkan kandungan gizi pada bubur bayi selain mensubstitusikan ikan pepetek yang ditepungkan, maka perlu ada kontribusi dari bahan lain seperti beras merah.

Untuk itu, perlu dilakukan penelitian untuk mengetahui formulasi bubur instan bayi yang tepat dengan memperhatikan aspek penerimaan dan kebutuhan zat gizi bayi. Pengembangan produk bubur instan bayi menggunakan substitusi tepung ikan 
pepetek (Leiognathus sp.) merupakan terobosan baru untuk menghasilkan MP-ASI yang mendukung pertumbuhan dan perkembangan bayi di atas 6 bulan.

\section{METODE PENELITIAN}

Jenis penelitian yang digunakan adalah metode eksperimen, yaitu melakukan percobaan pembuatan produk bubur instan dengan substitusi tepung ikan pepetek (Leiognathus sp.). Penelitian telah dilaksanakan pada bulan Januari dan Juni 2015. Proses pembuatan, uji organoleptik, dan analisis sifat fisik dilakukan di Laboratorium Teknologi Pangan Program Studi DIII Gizi Cirebon Politeknik Kesehatan Kemenkes Tasikmalaya, sedangkan untuk analisis kalsium dan protein pada substitusi bubur instan bayi terbaik dilakukan di Laboratorium Pangan, Universitas Pasundan Bandung.

Rancangan penelitian yang digunakan adalah Rancangan Acak Kelompok (RAK) dengan tiga perlakuan, masing-masing dilakukan 2 kali ulangan. Terdapat 4 perlakuan yang terdiri atas perbandingan bubur instan:tepung ikan pepetek berturut-turut formula 1 (100\%:0\%), formula 2 (75\%:25\%), formula 3 (50\%:50\%), formula 4 (25\%:75\%).

Pembuatan bubur instan mengikuti Elvizahro (2011) dengan bahan-bahan berupa beras merah, susu skim, minyak nabati, dan gula halus, sedangkan dalam pembuatan tepung ikan menggunakan ikan pepetek segar yang diperoleh dari nelayan yang berada di daerah Samadikun Kota Cirebon. Parameter pengujian organoleptik bubur bayi instan meliputi rasa, warna, tekstur, dan aroma. Uji organoleptik menggunakan metode uji hedonik menggunakan 30 orang panelis semi terlatih, yang bersedia menjadi panelis yaitu mahasiswa Program Studi DIII Gizi Cirebon sesuai dengan SNI 01-2346-2006. Uji kadar kalsium dilakukan dengan metode titrasi (Apriantono, 1989) dan uji kadar protein dilakukan dengan metode Kjeldahl (Bintang, 2010). Sifat fisik diperoleh dengan menghitung densitas kamba yaitu membagi berat bahan (dalam gram) dengan volume bahan (dalam mili liter).

Pengolahan data dilakukan dengan menggunakan perangkat lunak statistik. Data hasil pengukuran kadar kalsium, kadar protein, dan densitas kamba yang diperoleh ditabulasi dan dianalisis secara deskriptif. Data hasil uji organoleptik dianalisis secara deskriptif berdasarkan persentase panelis. Data tersebut diuji keragamannya menggunakan Anova (Analysis of Varian), dan dilanjutkan dengan Uji Duncan.

\section{HASIL DAN PEMBAHASAN}

\section{A. Pembuatan Bubur Instan Bayi}

Tahap persiapan awal dalam pembuatan bubur instan bayi diawali dengan membuat tepung ikan pepetek. Pembuatan tepung ikan diawali dengan pencucian dan penyiangan ikan, kemudian dilakukan pengkukusan selama 10 menit dengan menjaga suhu pengukusan $100^{\circ} \mathrm{C}$. Setelah itu, dilakukan pengepresan ikan yang sudah dikukus guna mempercepat proses selanjutnya yaitu pemanggangan atau pemanasan selama 5 jam dengan suhu $150{ }^{\circ} \mathrm{C}$. Tujuan pemanasan adalah mengurangi kadar air bahan sampai batas dimana perkembangan mikroorganisme dan kegiatan enzim yang dapat menyebabkan kebusukan terhambat atau terhenti agar bahan memiliki masa simpan yang lama (Taib, et al 1998). Setelah ikan pepetek kering, kemudian dilakukan penghalusan dengan blender, setelah halus tepung ikan pepetek disaring dengan ayakan 60 mesh.

Tahap selanjutnya dari pembuatan bubur instan bayi yaitu pembuatan bubur instan sebelum disubstitusi, yaitu membuat bubur susu instan dalam skala banyak dengan bahan baku $50 \mathrm{~g}$ susu skim, $35 \mathrm{~g}$ tepung beras merah, $10 \mathrm{~g}$ minyak nabati, dan $5 \mathrm{~g}$ gula halus, untuk bubur instan 100 g. Masing-masing bahan baku dibuat empat sebelum disubstitusi oleh tepung ikan pepetek. Untuk formulasi pertama yaitu $0 \%$ (kontrol) substitusi tepung ikan pepetek, bahan baku bubur instan seberat $100 \mathrm{~g}$ dimasak dengan air hingga menjadi adonan bubur, kemudian adonan bubur dihaluskan 
kembali dan setelah itu dilakukan pemanasan dengan suhu $150{ }^{\circ} \mathrm{C}$ selama 4 jam. Setelah adonan kering kemudian dihaluskan dan disaring dengan ayakan 60 mesh. Sama halnya dengan bubur instan kontrol, untuk formulasi substitusi tepung ikan pepetek $25 \%$ ditambahkan bahan baku bubur instan sebesar $75 \%$, untuk formulasi substitusi tepung ikan pepetek 50\% ditambahkan bahan baku bubur instan sebesar $50 \%$, dan untuk formulasi substitusi tepung ikan pepetek $75 \%$ ditambahkan bahan baku bubur instan sebesar $25 \%$, sehingga masing-masing formulasi substitusi tepung ikan pepetek memiliki berat $100 \mathrm{~g}$.

\section{B. Uji Organoleptik 1. Warna}

Penilaian warna pada produk bubur instan bayi yang telah disubstitusi tepung ikan pepetek merupakan penilaian subjektif panelis terhadap warna produk dengan menggunakan indera penglihatan. Penilaian organoleptik tersaji pada Tabel 1.

Tabel 1. Penilaian uji organoleptik secara hedonik terhadap warna bubur instan bayi

\begin{tabular}{lccc}
\hline $\begin{array}{l}\text { Formulasi } \\
\text { (Bubur instan } \\
\text { : Tepung ikan } \\
\text { pepetek) }\end{array}$ & $\begin{array}{c}\text { Ulangan } \\
\text { I }\end{array}$ & $\begin{array}{c}\text { Ulangan } \\
\text { II }\end{array}$ & $\begin{array}{c}\text { Rata- } \\
\text { Rata }\end{array}$ \\
\hline P1 & & & \\
$(100 \%: 0 \%)$ & 2,77 & 3,37 & $3,07^{\mathrm{a}}$ \\
P2 & & & \\
$(75 \%: 25 \%)$ & 3,20 & 3,53 & $3,36^{\mathrm{b}}$ \\
P3 & & & \\
$(50 \%: 50 \%)$ & 3,86 & 3,80 & $3,83^{\mathrm{c}}$ \\
P4 & & & \\
$(25 \%: 75 \%)$ & 2,77 & 3,03 & $2,9^{\mathrm{a}}$ \\
\hline
\end{tabular}

Keterangan:

*Skala hedonik: 1 (sangat tidak suka) - 5 (sangat suka).

${ }^{*}$ Huruf di atas angka (superscript) yang berbeda (a, b, dst.) secara statistik menunjukkan perbedaan yang signifikan pada nilai $\alpha=0,05$

Parameter warna bubur instan bayi dengan substitusi tepung ikan pepetek memperoleh nilai rata-rata berkisar sekitar 2,9 sampai 3,8 dengan nilai penampakan terbaik terdapat pada formulasi substitusi tepung ikan pepetek $50 \%$.
Hasil uji Anova menunjukkan bahwa setiap produk bubur instan bayi dengan substitusi tepung ikan pepetek berpengaruh nyata dengan nilai $p=0,000 \quad(p<0,05)$ terhadap tingkat kesukaan panelis terhadap parameter warna. Produk dengan formulasi substitusi $50 \%$ lebih disukai panelis, karena perpaduan warna kecoklatan bubur instan bayi dengan tepung ikan pepetek yang berwarna kuning menghasilkan warna yang cerah tidak kusam.

Hasil uji lanjut Duncan menunjukkan bahwa penampakan bubur instan yang telah disubstitusi tepung ikan tidak terdapat perbedaan pada formulasi masing-masing substitusi tepung ikan. Dengan nilai $p$ substitusi $75 \%$ dan $0 \%$ yaitu 0,22 ( $p>0,05)$ dan substitusi 25\% 50\%, 1.00 ( $p>0,05)$. Produk bubur instan yang disubstitusi tepung ikan pepetek $75 \%$ memiliki warna agak coklat kehitaman, sedangkan produk bubur instan yang tidak disubstitusi tepung ikan pepetek memiliki warna coklat agak pucat setelah diseduh dengan air panas. Warna tersebut dipengaruhi jumlah substitusi tepung ikan pepetek pada produk bubur instan. Tepung ikan berwarna kekuningan, dikarenakan tepung ikan mengandung senyawa pembawa sifat warna karoten, senyawa bernama xantophyl. Senyawa inilah yang menyebabkan warna kekuningan pada tepung ikan (Fisher, 2009)

Penampakan merupakan parameter organoleptik yang penting, karena merupakan sifat sensoris yang pertama kali dilihat oleh konsumen. Jika kesan penampakan produk terlihat baik atau disukai, maka konsumen akan melihat sifat sensoris lainnya (aroma, tekstur, rasa) (Soekarto, 1985).

\section{Aroma}

Penilaian aroma pada produk bubur instan bayi yang telah disubstitusi tepung ikan pepetek merupakan penilaian subjektif panelis terhadap aroma produk dengan menggunakan indera penciuman. Penilaian organoleptik tersaji pada Tabel 2. 
Tabel 2. Penilaian uji organoleptik secara hedonik terhadap aroma bubur instan bayi

\begin{tabular}{lccc}
\hline $\begin{array}{l}\text { Formulasi } \\
\text { (Bubur instan } \\
\text { : Tepung ikan } \\
\text { pepetek) }\end{array}$ & $\begin{array}{c}\text { Ulangan } \\
\text { I }\end{array}$ & $\begin{array}{c}\text { Ulangan } \\
\text { II }\end{array}$ & $\begin{array}{c}\text { Rata- } \\
\text { Rata }\end{array}$ \\
\hline $\begin{array}{l}\text { P1 } \\
(100 \%: 0 \%)\end{array}$ & 2,83 & 2,87 & $2,85^{\mathrm{a}}$ \\
P2 & & & \\
$(75 \%: 25 \%)$ & 3,37 & 3,00 & $3,18^{\mathrm{a}}$ \\
P3 & & & \\
$(50 \%: 50 \%)$ & 3,77 & 3,77 & $3,73^{\mathrm{b}}$ \\
P4 & & & \\
$(25 \%: 75 \%)$ & 2,67 & 3,03 & $2,81^{\mathrm{a}}$ \\
\hline
\end{tabular}

Keterangan:

*Skala hedonik: 1 (sangat tidak suka) - 5 (sangat suka). ${ }^{* *}$ Huruf di atas angka (superscript) yang berbeda (a, b, dst.) secara statistik menunjukkan perbedaan yang signifikan pada nilai $\alpha=0,05$

Parameter aroma bubur instan bayi yang telah disubstitusi tepung ikan pepetek memperoleh nilai rata-rata berkisar antara 2,8 sampai 3,7 dengan nilai rata-rata terbaik terdapat pada formulasi substitusi tepung ikan pepetek $50 \%$. Hal ini dikarenakan tidak ada aroma gurih yang dihasilkan oleh tepung ikan pada formulasi substitusi kontrol $0 \%$, seperti pada produk lain.

Hasil uji Anova menunjukkan bahwa setiap produk bubur instan bayi dengan substitusi tepung ikan pepetek berpengaruh nyata dengan nilai $p=0,000 \quad(p<0,05)$ terhadap tingkat kesukaan panelis terhadap parameter aroma. Produk dengan formulasi substitusi 50\% lebih disukai panelis, karena perpaduan aroma bubur instan dan tepung ikan sama besar.

Hasil uji lanjut Duncan menunjukkan bahwa aroma bubur instan yang telah disubstitusi tepung ikan pepetek tidak terdapat perbedaan pada formulasi substitusi tepung ikan pepetek $25 \%, 50 \%$, dan $75 \%$ dengan nilai $p=0,057(p>0,05)$ dan tidak terdapat perbedaan pada formulasi substitusi tepung ikan pepetek $50 \%$ dengan nilai $p 1.0(p>0,05)$. Penilaian panelis terhadap aroma produk sangat subjektif, tergantung kesukaan masingmasing panelis terhadap produk olahan ikan. Perubahan aroma merupakan proses menghilangnya bahan volatil, karamelisasi karbohidrat, dekomposisi protein dan lemak serta koagulasi protein yang disebabkan oleh pemanasan (Dawson 1959 diacu dalam Mountney 1966). Aroma yang timbul berupa aroma karamelisasi susu dan gula pada bahan produk bubur instan bayi dan aroma khas ikan. Produksi senyawa-senyawa aroma ditentukan oleh komposisi kimia dari produk, enzim-enzim yang terlibat di dalamnya, maupun bakteri yang terlibat dalam senyawa tersebut (Winarno, 2004).

\section{Tekstur}

Penilaian tekstur pada produk bubur instan bayi yang telah disubstitusi tepung ikan pepetek merupakan penilaian subjektif panelis terhadap kelembutan produk dengan menggunakan indera pengecap. Penilaian organoleptik tersaji pada Tabel 3.

Tabel 3. Penilaian uji organoleptik secara hedonik terhadap tekstur bubur instan bayi

\begin{tabular}{lccc}
\hline $\begin{array}{l}\text { Formulasi } \\
\text { (Bubur instan } \\
\text { : Tepung ikan } \\
\text { pepetek) }\end{array}$ & $\begin{array}{c}\text { Ulangan } \\
\text { I }\end{array}$ & $\begin{array}{c}\text { Ulangan } \\
\text { II }\end{array}$ & $\begin{array}{c}\text { Rata- } \\
\text { Rata }\end{array}$ \\
\hline $\begin{array}{l}\text { P1 } \\
(100 \%: 0 \%)\end{array}$ & 3,03 & 2,60 & $2,81^{\mathrm{a}}$ \\
P2 & & & \\
$(75 \%: 25 \%)$ & 3,43 & 3,00 & $3,21^{\mathrm{ab}}$ \\
P3 & 3,23 & 3,67 & $3,45^{\mathrm{c}}$ \\
$(50 \%: 50 \%)$ & & & \\
P4 & 3,03 & 3,13 & $3,07^{\mathrm{b}}$ \\
\hline$(25 \%: 75 \%)$ & 3,03 & \\
\hline
\end{tabular}

Keterangan:

*Skala hedonik: 1 (sangat tidak suka) - 5 (sangat suka).

**Huruf di atas angka (superscript) yang berbeda (a, b, dst.) secara statistik menunjukkan perbedaan yang signifikan pada nilai $\alpha=0,05$

Parameter tekstur bubur instan bubur instan bayi yang telah disubstitusi tepung ikan pepetek memperoleh nilai rata-rata berkisar antara 2,8 sampai 3,7 dengan nilai rata-rata terbaik terdapat pada formulasi substitusi tepung ikan pepetek $50 \%$.

Hasil uji Anova menunjukan bahwa setiap produk bubur instan bayi dengan substitusi tepung ikan pepetek berpengaruh nyata dengan nilai $p=0.000 \quad(p<0,05)$ terhadap tingkat kesukaan panelis terhadap 
parameter tekstur. Produk dengan formulasi substitusi 50\% lebih disukai panelis, karena perpaduan tekstur bubur instan dan tepung ikan sama besar. Tekstur adalah sekelompok sifat fisik yang ditimbulkan oleh elemen struktural bahan pangan yang dapat dirasa oleh perabaan, terkait dengan deformasi, desintegrasi dan aliran dari bahan pangan dibawah tekanan yang diukur secara obyektif oleh fungsi masa, waktu, dan jarak (Purnomo 1995 diacu dalam Yuniarti 2000). Makanan yang sesuai untuk bayi 6 bulan ke atas adalah makanan dengan tekstur semipadat. Dalam spesifikasi menurut Kemenkes RI nomor 224/Menkes/SK/II/2007 disebutkan bahwa MP-ASI bubuk instan apabila dicampur dengan air akan menghasilkan bubur halus tanpa gumpalan dengan kekentalan yang memungkinkan pemberian dengan sendok. MP-ASI instan juga harus berupa partikel dengan ukuran cukup untuk memacu bayi agar dapat mengunyah (Elvizahro, 2011). Produk dengan formulasi substitusi $75 \%$ tidak terlalu lembut karena didominasi oleh tepung ikan pepetek.

Hasil uji lanjut Duncan menunjukan bahwa aroma bubur instan yang telah disubstitusi tepung ikan tidak terdapat perbedaan pada substitusi $0 \%$ dan $75 \%$ dengan nilai $p=0,064 \quad(p>0,05)$. Pada substitusi $75 \%$ dan $25 \%$ juga tidak terdapat perbedaan nyata dengan nilai $p=0,458$ ( $p>0,05)$. Pada substitusi $50 \%$ tidak terdapat perbedaan nyata dengan nilai $p=1.000$ $(p>0,05)$ terhadap tingkat kesukaan panelis pada parameter tekstur. Hal ini karena seluruh bubur instan yang dibuat, menggunakan pengayakan yang sama yaitu ayakan 60 mesh, sehingga bubur instan bayi yang dihasilkan tidak jauh berbeda.

\section{Rasa}

Penilaian rasa pada produk bubur instan bayi yang telah disubstitusi tepung ikan pepetek merupakan penilaian subjektif panelis terhadap rasa produk dengan menggunakan indera pengecap. Penilaian organoleptik tersaji pada Tabel 4.
Tabel 4. Penilaian rata-rata uji organoleptik secara hedonik terhadap rasa bubur instan bayi

\begin{tabular}{|c|c|c|c|}
\hline $\begin{array}{l}\text { Formulasi } \\
\text { (Bubur instan : } \\
\text { Tepung ikan } \\
\text { pepetek) }\end{array}$ & $\begin{array}{c}\text { Ulangan } \\
\text { I }\end{array}$ & $\begin{array}{c}\text { Ulangan } \\
\text { II }\end{array}$ & $\begin{array}{l}\text { Rata- } \\
\text { Rata }\end{array}$ \\
\hline $\begin{array}{l}\mathrm{P} 1 \\
(100 \%: 0 \%)\end{array}$ & 2,76 & 2,67 & $2,71^{a}$ \\
\hline $\begin{array}{l}\text { P2 } \\
(75 \%: 25 \%)\end{array}$ & 3,47 & 3,07 & $3,27^{b}$ \\
\hline $\begin{array}{l}\text { P3 } \\
(50 \%: 50 \%)\end{array}$ & 3,83 & 4,10 & $3,96^{c}$ \\
\hline $\begin{array}{l}\text { P4 } \\
\text { (25\% : 75\%) }\end{array}$ & 2,87 & 2,90 & $2,90^{\mathrm{a}}$ \\
\hline
\end{tabular}

Keterangan:

*Skala hedonik: 1 (sangat tidak suka) - 5 (sangat suka). ${ }^{* *}$ Huruf di atas angka (superscript) yang berbeda (a, b, dst.) secara statistik menunjukkan perbedaan yang signifikan pada nilai $\alpha=0,05$

Parameter rasa bubur instan bayi yang telah disubstitusi tepung ikan pepetek memperoleh nilai rata-rata berkisar antara 2,7 sampai 3,9 dengan nilai rata-rata terbaik terdapat pada formulasi substitusi tepung ikan pepetek $50 \%$. Hal ini disebabkan produk kontrol memiliki rasa murni bubur instan bayi yang tidak terlalu manis, sehingga panelis cenderung tidak menyukai. Pada formulasi lain terdapat rasa gurih produk ikan yang akrab di indera perasa panelis, sehingga panelis cenderung menyukai.

Rasa merupakan faktor yang sangat menentukan pada keputusan akhir konsumen untuk menerima atau menolak suatu makanan. Menurut Kemenkes RI nomor 224/Menkes/SK/II/2007 pada karakteristik produk, terdapat tiga rasa yang disukai bayi yaitu beras merah, kacang hijau, dan pisang.

Hasil uji Anova menunjukan bahwa setiap produk bubur instan bayi dengan substitusi tepung ikan pepetek berpengaruh nyata dengan nilai $p \quad 0,000 \quad(p<0,05)$ terhadap tingkat kesukaan panelis untuk parameter rasa. Produk dengan formulasi substitusi $50 \%$ lebih disukai panelis, karena perpaduan rasa bubur instan dan tepung ikan yang pas, tidak terlalu manis dan 
ditambah rasa gurih yang tidak terlalu terasa.

Hasil uji lanjut Duncan menunjukan bahwa aroma bubur instan yang telah disubstitusi tepung ikan tidak terdapat perbedaan pada substitusi $0 \%$ dan $75 \%$ dengan nilai $p=0,216(p>0,05)$ dan pada substitusi $25 \%$ dan $50 \%$ dengan nilai $p=$ $1.000(p>0,05)$ terhadap tingkat kesukaan panelis pada parameter rasa. $\mathrm{Hal}$ ini diduga karena pada produk formulasi substitusi tepung ikan pepetek $75 \%$ memiliki rasa gurih ikan yang terlalu kuat, mengingat ikan pepetek sendiri sudah memiliki rasa asin. Berdasarkan keseluruhan produk, bubur bayi yang dihasilkan memiliki rasa manis dan gurih. Rasa manis berasal dari pemakaian gula bubuk dan susu skim. Namun menurut Elvizahro (2011), susu skim juga membuat produk bubur instan bayi terasa gurih selain dari tepung ikan. Pemakaian gula harus dibatasi karena kadar kemanisan yang tinggi dapat menyebabkan bayi mudah kenyang.

\section{Hasil Substitusi Tepung Ikan Pepetek Terbaik Pada Bubur Instan Bayi}

Berdasarkan uji organoleptik dapat diketahui nilai kesukaan terhadap warna, aroma, rasa, dan tekstur dari masingmasing formula substitusi tepung ikan pepetek tertera pada Gambar 1.

Hasil Uji Organoleptik Bubur

Instan Bayi Dengan Subtitusi Ikan

Pepetek

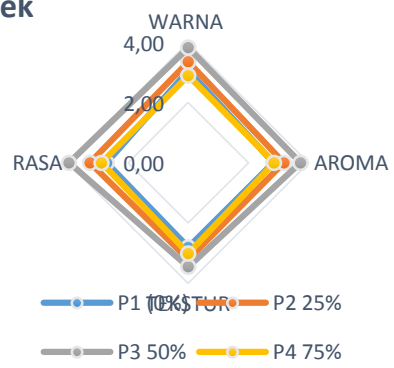

Gambar 1. Rata-rata penilaian organoleptik bubur instan bayi substitusi ikan pepetek

Pedoman dasar yang digunakan dalam pembuatan formula substitusi tepung ikan pepetek pada produk bubur instan bayi adalah angka kebutuhan gizi bayi yang meliputi protein dan kalsium. Menurut WNPG (2004), bayi yang berada pada rentang umur 7-11 bulan dan memiliki berat badan $8,5 \mathrm{~kg}$ membutuhkan energi $650 \mathrm{kkal}$ dan protein $16 \mathrm{~g}$. Keputusan Menteri Kesehatan RI nomor 224/Menkes/SK/II/ 2007 juga menjadi acuan dalam penelitian ini, dimana setiap 100 gram MP-ASI harus mengandung protein berkisar 15 sampai 22 $\mathrm{g}$ dan kalsium berkisar 200 sampai 400 mg.

Substitusi terbaik dipilih berdasarkan penilaian panelis melalui uji organoleptik terhadap parameter warna, aroma, tekstur, dan rasa. Diperoleh hasil satu produk yang terbaik meliputi warna, aroma, tekstur, dan rasa yaitu pada produk bubur instan bayi yang telah disubstitusi tepung ikan pepetek $50 \%$ dengan rata-rata kesukaan 3,74 (mendekati suka), sehingga pada tahap selanjutnya untuk pengukuran sifat fisik (densitas kamba), kadar protein, dan kadar kalsium dilakukan pada perlakuan yang terbaik ini (substitusi 50\% tepung ikan Pepetek).

Berdasarkan hasil uji Anova terdapat pengaruh substitusi tepung ikan pepetek terhadap warna dan rasa pada formulasi produk bubur instan. Produk bubur instan dengan substitusi ikan pepetek 50\% memiliki warna kuning kecoklatan serta rasa yang pas, tidak terlalu gurih.

\section{Densitas Kamba Produk Bubur Instan Bayi Terbaik}

Nilai densitas kamba produk bubur instan bayi dengan substitusi tepung ikan terbaik $50 \%$ adalah $0,52 \mathrm{~g} / \mathrm{ml}$. nilai tersebut berada dalam rentang densitas kamba bubur komersial, yaitu 0,37-0,5 g/ml dan dapat dianggap telah memenuhi spesifikasi Keputusan Kementerian Kesehatan RI, yaitu bubur instan dengan substitusi tepung ikan pepetek 50\% tidak kamba. Densitas kamba merupakan salah satu sifat fisik dari makanan yang berbentuk partikel bubuk atau padatan. Densitas kamba dihitung dengan mengetahui besarnya nilai massa partikel bubuk yang menempati suatu unit 
volume tertentu (Wiratakusumah, et al 1992).

Produk bubur bayi tidak boleh bersifat kamba karena akan cepat memberi rasa kenyang. Suatu bahan dikatakan kamba apabila mempunyai nilai densitas kamba yang kecil (Elvizahro, 2011). Densitas kamba merupakan salah satu indikator keberhasilan dari produk makanan bubuk atau padatan. Bubur instan bayi dengan nilai densitas yang tinggi sangat diharapkan karena produk dengan nilai gizi tinggi akan menempati volume ruang yang kecil pada usus bayi, sehingga zat gizi yang dapat diserap oleh bayi semakin banyak (Wiratakusumah dkk., 1992). Nilai densitas kamba kecil akan menempati volume ruang yang lebih besar pada usus bayi sehingga menyebabkan bayi merasa cepat kenyang, namun asupan gizinya belum terpenuhi (Arifianti, 2012). Kapasitas fungsional lambung bayi hanya $30 \mathrm{~g} / \mathrm{Kg}$ berat badan sehingga makanan dengan volume yang kecil diperlukan agar bayi menjadi tidak cepat kenyang dan asupan gizinya terpenuhi (Elvizahro, 2011)

\section{E. Kadar Protein dan Kalsium Produk Bubur Instan Bayi Terbaik}

Nilai protein pada produk bubur instan bayi dengan substitusi tepung ikan pepetek terbaik $50 \%$ adalah $21,89 \%$. Protein merupakan suatu zat makanan yang sangat penting bagi tubuh, karena zat ini disamping berfungsi sebagai bahan bakar dalam tubuh juga berfungsi sebagai zat pembangun dan pengatur (Winarno, 2004). Protein pada bayi sebaiknya yang bermutu tinggi, sedapat mungkin mirip dengan kasein dan protein whey yang terdapat dalam ASI (Wuryo, 2002)

Menurut Kemenkes RI nomor 224/Menkes/SK/II/2007, kadar protein dalam MP-ASI bubuk instan berkisar antara 15$22 \%$. Maka, dari hasil analisis kadar protein yang dilakukan terhadap produk bubur instan bayi yang telah disubstitusi tepung ikan pepetek $50 \%$, kadar protein yang diperoleh sudah memenuhi spesifikasi dari
Keputusan Menteri Kesehatan RI yaitu $21,89 \%$.

Nilai kalsium pada produk bubur instan bayi dengan substitusi tepung ikan pepetek terbaik $50 \%$ adalah $185,19 \mathrm{mg}$. Kalsium meupakan salah satu mineral yang paling banyak didapat di dalam tubuh dan dibutuhkan dalam jumlah relatif banyak. Selama ini kalsium lebih banyak dikenal sebagai unsur penting untuk tulang dan gigi. Sebenarnya kalsium juga diperlukan untuk hampir sebagian besar fungsi tubuh. Kemampuan optimal tubuh menyerap kasium dan membentuk tulang adalah pada usia sebelum 35 tahun (Djunaedi, 2002).

Fungsi kalsium antara lain untuk pembentukan tulang dan gigi, berperan dalam pertumbuhan dan sebagai faktor pembantu dan pengatur reaksi biokimia dalam tubuh. Pada tulang, kalsium dalam bentuk garam (hydroxypatite) membentuk matriks pada kolagen protein pada struktur tulang membentuk rangka yang mampu menyangga tubuh serta tempat bersandarnya otot yang menyebabkan memungkinkan terjadinya gerakan (Goulding, 2000), sehingga sangat penting bagi bayi usia $6-12$ bulan yang sedang dalam tahap tumbuh dan berkembang.

Menurut Kemenkes RI nomor 224/Menkes/SK/II/2007, kadar kalsium dalam MP-ASI bubuk instan berkisar antara 200-400 mg per $100 \mathrm{~g}$. Hasil analisis kadar kalsium yang dilakukan terhadap produk bubur instan bayi yang telah disubstitusi tepung ikan pepetek $50 \%$, kadar kalsiumnya belum memenuhi spesifikasi dari Kepmenkes tersebut yaitu 185,19 mg/100g. Kurang cukupnya kadar kalsium pada bubur instan bayi yang telah disubstitusi tepung ikan pepetek tidak terlalu signifikan, dapat disempurnakan dengan pemberian ASI yang cukup. Jika analisis dilakukan pada formulasi susbstitusi tepung ikan pepetek $75 \%$, kemungkinan kadar kalsium dalam bubur instan ini akan tercapai sesuai dengan Kepmenkes RI. 


\section{KESIMPULAN}

1. Substitusi Tepung Ikan Pepetek terbaik dipilih berdasarkan penilaian panelis melalui uji organoleptik terhadap parameter warna, aroma, tekstur, dan rasa. Hasil uji organoleptik menyatakan, substitusi ikan terbaik adalah substitusi tepung ikan pepetek $50 \%$.

2. Hasil uji organoleptik menunjukkan bahwa ada pengaruh substitusi tepung Ikan Pepetek terhadap parameter warna, aroma, tekstur, dan rasa bubur instan bayi $(p=0,000)$.

3. Hasil analisis fisik produk bubur instan terbaik hasil susbtitusi tepung ikan Pepetek (50\%) yaitu densitas kamba adalah $0,53 \mathrm{mg} / \mathrm{ml}$, artinya tidak kamba.

4. Hasil analisis protein dan kalsium dari produk bubur instan bayi dengan substitusi tepung ikan pepetek terbaik $(50 \%)$ adalah Kadar protein bubur instan bayi $21,89 \%$, artinya sudah memenuhi spesifikasi Keputusan Menteri Kesehatan RI tahun 2007. Untuk kadar kalsium bubur instan bayi terbaik adalah 185,19 $\mathrm{mg} / 100 \mathrm{~g}$, artinya belum memenuhi spesifikasi Keputusan Menteri Kesehatan RI tahun 2007 yang mensyaratkan minimal $200 \mathrm{mg} / 100 \mathrm{~g}$.

\section{SARAN}

Saran dari hasil penelitian ini adalah perlu dilakukan analisis proksimat yaitu kadar air, kadar lemak, kadar abu, dan karbohidrat terhadap masing-masing perlakuan substitusi tepung ikan pepetek. Perlu dilakukan uji karakteristik produk tentang daya tahan produk bubur instan dengan substitusi tepung ikan pepetek, agar mengetahui seberapa lama produk aman dikonsumsi setelah diproduksi. Selain itu, perlu digunakan drum dryer untuk proses pengeringan tepung ikan maupun bubur instan agar tidak memerlukan waktu lama dalam proses pembuatan produk dan produk diolah dengan menggunakan teknologi tinggi.

\section{DAFTAR PUSTAKA}

Anonim. Direktorat Jenderal Perikanan. 1998. Program Peningkatan Ekspor Hasil Perikanan (PRO-TEKAN) 2003. Direktorat Jenderal Per- ikanan, Jakarta. $29 \mathrm{hlm}$. Diakses 12 Oktober 2014.

Apriadji, W.J \& M. Ariani. 1 989. Gizi Bayi. Penebar Swadaya. Jakarta

Apriyantono A, dkk. 1989. Analisis Pangan. Bogor: Pusat Antar Universitas Pangan dan Gizi, Institut Pertanian Bogor.

Arifianti, A., Katri A, R.B., Rachmawanti A, D., Riyadi P, N.H. 2012. Karakterisasi Bubur Bayi Instan Berbahan Dasar Tepung Millet (Panicum sp) Dan Tepung Beras Hitam (Oryza sativa L. Japonica) Dengan Flavor Alami Pisang Ambon (Musa paradisiaca var. sapientum). Jurnal Teknosains Pangan, 1(1), 1-8

Bintang, Maria. 2010. Biokimia teknik Penelitian. Jakarta: Erlangga

Dahuri et., al 2001. Pengelolaan sumberdaya wilayah pesisir dan lautan terpadu. Jakarta. $292 \mathrm{hlm}$. Cuvier.

Depkes RI. 2001. http//www.depkes.go.id. Diakses 11 Oktober 2014.

Depkes 2006 MP-ASI. Departemen kesehatan RI. 2006. Pedoman umum pemberian makanan pendamping air susu ibu (MP-ASI) lokal tahun 2006. Depkes RI. Jakarta

Departemen Kelautan dan Perikanan (DKP) - Lembaga IImu Pengetahuan Indonesia (LIPI), 2001. Pengkajian Stok Ikan di Perairan Indonesia. Jakarta.

Direktorat Gizi Depkes RI. 2008. Daftar Komposisi Bahan Makanan. Jakarta. Bharata.

Direktorat Jenderal Perikanan. 1997. Jaring Trawl dan Jaring yang Menyerupai Trawl tetapi bukan Trawl, Juklak SK Mentan No. 503/Kpts/Um/7/1980.

Djunaedi, H. 2002. Kalsium. Majalah Kesehatan Masyarakat Indonesia Vol. 30 no 2 November 2002.

[DKP] Departemen kelautan dan perikanan. 2001. Statistik Perikanan Tangkap 
Indonesia Tahun 1999. Departemen kelautan dan Perikanan RI. Jakarta.

Elvizahro, L. 2011. Kontribusi MP-ASI Bubur Bayi Instan Dengan Subitusi Tepung Ikan Patin dan Tepung Labu Kuning Terhadap Kecukupan Protein dan Vitamin A Pada Bayi [skripsi]. Universitas Diponegoro Semarang.

Fernando, Ryzki Edo. 2008. Formulasi bubur susu kacang tanah instan sebagai alternatif makanan pendamping asi [skripsi]. Fakultas pertanian. Prodi gizi masyarakat dan sumberdaya keluarga. Institut Pertanian Bogor.

Fisher. 2009. Tepung Ikan. http://nakedfisher.blogspot.com/2009/0 6/tepung-ikan.html. Diakses tanggal 7 Juni 2015.

Goulding A, et al. 2000. Children Who Avoid Drinking Cows's Milk at Increased Risk for Prepubertal Bone Factures. Journal of The American Dietetic

Association,2004; 104 (2): 250-253

Putro, Jati Sumarto, I Wayan Budiastra dan Usman Ahmad. 2012. Optimasi Proses Penggorengan Hampa dan Penyimpanan Keripik Ikan Pepetek (Leiognathus sp.) Jurnal keteknikan pertanian. Institut Pertanian Bogor

Mountney, G.J. 1966. Poultry Product Technology. The Avi Pub. Co. Inc. Westport, Connecticut.

Peraturan Menteri Kesehatan RI no 75 th. 2013. AKG bagi Bangsa Indonesia Peraturan Menteri Kesehatan RI NO. 75 th. 2013. Lampiran Angka Kecukupan Gizi yang dianjurkan Bagi Bangsa Indonesia. Jakarta.

Purnomo, H. 1995. Aktivitas Air dan Peranannya dalam Pengawetan Makanan. UI press. Jakarta.

[SNI] Standar Nasional Indonesia. 2005. Makanan Pendamping Air Susu ibu Bagian 1: bubuk instan. Badan Standardisasi Nasional. Jakarta. (SNI 01-7111.4-2005)

[SNI] Standar Nasional Indonesia. 2011. Petunjuk pengujian organoleptik dan atau sensori pada produk perikanan. Badan Standardisasi Nasional. Jakarta. (SNI 01-2346-2006)

Sudarmadji, Slamet, Bambang Haryono, dan Suhardi. 1989. Analisa bahan makanan dan pertanian. Yogya: PAUGajah Mada 1989 (182 Hal.) 346.

Soekarto, S.T., 1990. Dasar-Dasar Pengawasan dan Standarisasi Mutu Pangan. Jurusan Teknologi Pangan dan Gizi. Departemen Pendidikan dan Kebudayaan. Direktorat Jenderal Pendidikan Tinggi. Pusat Antar Universitas Pangan dan Gizi Institut Pertanian Bogor, Bogor.

Soekarto, S.T, 2985. Penilaian Organoleptik Untuk Industri Pangan dan Hasil Pertanian. Jakarta: Bhatara Karya Aksara.

Susenas Depkes. 2006. Survei Kesehatan Nasional (Susenas) Tahun 2005: Antropometri 1989-2005. www.gizi.net Diakses 09 Oktober 2014

Taib. G., G. Said \& Swiramadja.1 998. Operasi Pengeringan pada Pengolahan Hasil Pertanian. Media Tama Sarana Perkasa. Jakarta.

WHO. 2002. Infant and young child nutrition. http://www.who.int/nutrition/publications /infantfeeding/9241562218/en/index.ht $\mathrm{ml}$

--WHO/UNICEF, 2003. Global Strategy for Infant and Young Child Feeding. Geneva, World Health Organization.

Widyakarya Nasional Pangan dan Gizi (WNPG). 2004. Jakarta: Lembaga IImu Pengetahuan Indonesia.

Winarno, F.G. 1995. Gizi Makanan Bagi Bayi dan Anak Sapihan: Pengadaan dan Pengolahan. Pustaka Sinar Harapan. Jakarta.

Winarno, F.G.. 2004. Kimia Pangan dan Gizi. Jakarta: Gramedia Pustaka Utama Wiratakusumah, M.A. K. Abdullah \& A.M. Syarief. 1992. Sifat Fisik Pangan. PAU Pangan dan Gizi IPB. Bogor. 